http://dx.doi.org/10.12775/szhf.2017.032

\author{
DARIUSZ KUCHARSKI \\ Cardinal Stefan Wyszyński University, Warsaw, Poland \\ E-MAIL:D.KUCHARSKI@UKSW.EDU.PL
}

\title{
Robert Boyle vs. Henry More on Acquiring Knowledge. Religious Concerns of the Seventeenth-Century Philosophy in England
}

In the famous Leviathan and the air-pump by Shapin and Shaffer, ${ }^{1}$ we find, among others, an interpretation of the discussion which ensued between Henry More and Robert Boyle after the publication of New Experiments Phisico-Mechanical, touching the Spring of the Air issued in 1660 by the latter. The authors of the Leviathan present this discussion as a dispute between a representative of experimental philosophy on the one hand and a defender of some certain theological theses, using for that purpose some arguments in natural philosophy on the other. Shapin and Shaffer define the goals of their book as follows: "Our subject is experiment. We want to understand the nature and status of experimental practices and their intellectual products. ... Behind (some) particular questions lie more general ones: Why does one do experiments in order to arrive at scientific truth? Is experiment a privileged means of arriving at consensually agreed knowledge of nature, or are other means possible? What recommends the experimental way in science

${ }^{1}$ S. Shapin i S. Schaffer, Leviathan and the air-pump. Hobbes, Boyle, and the experimental life, Princeton and Guildford: Princeton University Press, 1985. 
over alternatives to it? We want our answers to be historical in character. To that end, we will deal with the historical circumstances in which experiment as a systematic means of generating natural knowledge arose, in which experimental practices became institutionalized, and in which experimentally produced matters of fact were made into the foundations of what counted as proper scientific knowledge. We start, therefore, with that great paradigm of experimental procedure: Robert Boyle's researches in pneumatics and his employment of the air-pump in that enterprise". ${ }^{2}$

What follows is a famous account of Boyle's experiments, of developing the 'experimental way of life' and his defense of the experimental program against fierce critique from many different directions. The main antagonist of Boyle in this respect was obviously T. Hobbes, but among other adversaries we meet Henry More.

Shapin and Shaffer picture More as a proponent of a certain neoplatonic, metaphysical stance that was taken mainly for theological and apologetic reasons. As they point out, in his Collection of Several Philosophical Writings (1662) More defines his fundamental goals, namely, to defend true religion from the danger of some radical sectaries, Hobbist mechanists and enthusiasts. One of the most important parts of this enterprise was to be the field of natural philosophy, where More hoped to prove the existence and necessary causal activity of some spiritual agents and finally of God himself. That is why he introduces in his ontology a 'Spirit of Nature', which was to play explanatory role in those natural phenomena, the mere mechanical principles he could not, sufficiently according to More, explain. 'Spirit of Nature', being thoroughly dependent 'vicarious power of God', was to be the real cause of all natural phenomena of the material world. ${ }^{3} \mathrm{R}$. Boyle's experiments were perceived by More in that perspective; they brought just a new possible source of arguments in favor of existence and agency of spiritual principles in nature. And consequently, More in his Antidote against Atheism argued that experimental work must display the real action of spirit in nature. The outcomes of experiments could be a powerful weapon against the atheists; products of such experimentation being summoned with the use of some modern methods and philosophical insights would reinforce a proper theology. More

\footnotetext{
2 Ibid., p. 3.

${ }^{3}$ The evolution of notion of 'Spirit of Nature' in H. More and his metaphysics see: J. Reid, The Metaphysics of Henry More, Springer, Dordrecht, Heidelberg-New York-London 2012.
} 
found it absolutely essential that defenders of true religion should "talk with the Naturalists in their own Dialect". ${ }^{4}$

According to Shapin and Schaffer, More, aiming at the above mentioned goals, rewrote Boyle's experimental reports for his own purposes accepting their value as matters of fact and emphasizing the importance of those places where Boyle acknowledged the apparent purposiveness of natural action. Where Boyle excluded the attributes of soul from natural philosophy, More interpreted that as a limitation on the attributes of matter in nature and in proper theology. More refused to acknowledge or use the power of spring, which he persistently made out as a mark of the ultimate limits on the mechanical philosophy. "Finally, he insisted that natural philosophy's products be used as weapons in theology: this was, in fact, their best and only proper function. These contrasts became explicit conflicts after 1662. They centered on different conceptions of the function of Boyle's programme, different patterns of exploitation of matters of fact, and therefore different forms of life in experimental philosophy and in religion". ${ }^{5}$

In Shapin and Shaffer's view, the essential issue about experimental philosophy that More could not accept was its alleged independence of any metaphysics and consequently of any theology. Experiments could not be treated as an enterprise without any further commitments in terms of achieving certain metaphysical and theological goals. As he wrote in 1676, "Elastick Philosophers ... make experiments for experiments sake, or to pass away the time, or to be thought great natural or rather mechanical Philosophers, and that in hope to shew, that all the Phaenomena of Nature may be performed without the present assistance or guidance of any immaterial Principle". ${ }^{6}$ Ac-

${ }^{4}$ H. More, "An Antidote against atheism", bk 2, ch 2, sec 1 in: A Collection of Several Philosophical Writings, J. Flesher for W. Morden, London 1662, p. 40. The individual works in this collection are separately paginated. Many thinkers of that time were aware of the need of using some modern ideas in natural philosophy in order to defend certain religious theses, see for example S. Patrick, A brief account of the new sect of latitude-men. Together with some reflections upon the new philosophy, London 1662, "I hear some men say, all innovations are dangerous ... new Philosophy will bring in new Divinity... [Yet] true Philosophy can never hurt found Divinity", pp. 22-24 and "Nor will it be posible otherwise to free religion from scorn and contempt if her priests be not as well skilled in nature as the people, and her champions furnished with as good artillery as her enemies... and fight with them at their own weapons", p. 24.

${ }^{5}$ S. Shapin and S. Schaffer, Leviathan and the air-pump, p. 212.

${ }^{6} \mathrm{H}$. More, Remarks on two late ingenious discourses, p. 189. http://quod.lib.umich.edu/e/ eebo/A51313.0001.001/1:7.17?rgn=div2; view=fulltext (access 19.07.2017). 
cording to More, such a superficial attitude limiting the usage of experiment only to natural philosophy was not acceptable. More claimed that the outcomes of experimental work were legitimately useful outside natural philosophy, and indeed, they could only fulfill their purpose inside true religion.

Obviously, Boyle took a very different position towards the scope and goals of his experimental philosophy. First of all, he questioned the availability of results of experimental work outside the boundaries of the experimental community. Boyle defended the autonomy and special status of this community throughout his discussions with More. As Shapin and Shaffer point out, Boyle used several means for that purpose. He chose a certain structure of the text, insisted on proper manners in dispute, expressed his position on the proper place of spirit in experimental philosophy, and provided detailed description of specific experiments. What seems to be crucial, Boyle claimed that matters of fact, established during the experimental work, were not open to indefinite reinterpretation by those outside the community of experimental philosophers. Boyle insisted that some items could become the objects of experimental discourse and others could not. The power of the air pressure, for example, was "not a thing deduced" from "doubtful suppositions or bare hypotheses, but from real and sensible experiments". So this power was a matter of fact; nevertheless, its cause remained in doubt, but, according to Boyle, "we ought rather to acknowledge our ignorance in a doubtful problem, than deny what experience manifests to be a truth". Such was the case with experimentations in the field of magnetism (where the cause was equally uncertain) or with the effects of air pressure on living bodies (where result was not yet reliable). ${ }^{7}$

As we have seen, Shapin and Schaffer focus mainly on issues related to the emerging "experimental way of life" and its struggle to secure a proper place for itself in the whole system of knowledge. Shapin and Schaffer's interpretation of the above discussion is obviously a part of a much broader enterprise of explaining the emergence of the modern science. And, as we know, this enterprise has been proven very influential in the history of philosophy and the history of science. But it has been over 30 years now since the publication of Leviathan, and during these years enormous scholarly work on variety of is-

7 The detailed discussion on Boyle-More controversy see S. Shapin and S. Schaffer, Leviathan and the air-pump, pp. 207-224; quotations: R. Boyle, "New experiments about differing pressure" in: The Works of the Honourable Robert Boyle, London 1772, vol. 3, p. 643.

https://books.google.pl/books?id=O0xTAAAAcAAJ\&printsec $=$ frontcover\&hl=pl\# $\mathrm{v}=$ onepage \&q\&f=false (access 14.072017). 
sues related to the XVII ${ }^{\text {th }}$ century philosophy and culture in general has been done, which influenced our perception of that period. At the beginning of their book, Shapin and Schaffer claimed: "We want our answers to be historical in character. To that end, we will deal with the historical circumstances in which experiment as a systematic means of generating natural knowledge arose". Do we not agree? But in the light of the last decades research, the answers, in order to be 'historical in character', must come from even broader perspective. One of the outcomes of that research is growing interest in the position of religion and theology within the scope of philosophical discussion and manifold changes of the modern age. So now we can see some old problems in a relatively new light; it also applies to the More-Boyle controversy about the nature of knowledge and matter. Before we go to see their discussion in the new light, we need to have a look at some theological issues that formed the XVII ${ }^{\text {th }}$ century minds.

The setting of spiritual and intellectual life in England of this period was heavily influenced by the problem of Adam's Fall in Paradise and its consequences for mankind. And that very fact was an important part of a set of ideas making up the phenomenon of 'millenarianism' that accompanied Christianity for centuries but enjoyed a particularly intensive revival in the $\mathrm{XVII}^{\text {th }}$ century ${ }^{8}$.

The story of the Fall of Man in Paradise has always been one of the most important components of the Christian culture and fascinated Western minds. Some scholars describe it as 'the anthropological myth par excellence, 'the most elemental of myths', and 'the central myth of Western culture.' During the seventeenth century, this myth attracted unusual attention of many philosophers and theologians and became particularly important as a very influential background of intellectual life. At the same time, the Bible came to occupy a position of unparalleled authority, playing an essential role in many different fields of both public and private life. The Bible informed discussions about literally all the spheres of life and in all of them the story of Adam had a significant place. According to historian Christopher Hill, "The Fall then was central to seventeenth-century debates about the nature of the state and its laws, as well as about the justification of private property, social inequality

\footnotetext{
8 The meaning of millenarian tradition for emerging the modern world view see: D. Noble, The religion of technology. The divinity of man and the spirit of invention, A.A. Knopf, New York 1998; millenarianism in England of the period see: The millenarian turn: millenarian contexts of science, politics, and everyday anglo-american life in the seventeenth and eighteenth centuries ed. J. E. Force and R. H. Popkin, Springer Science-Business Media, Dordrecht 2001.
} 
and the subordination of women". ${ }^{9}$ In fact, the myth of the Fall was equally relevant to the development of certain ideas in philosophy; it informed discussions about the foundations of knowledge and influenced methodological developments in the emerging natural sciences. This was the case particularly in England where Calvinist understandings of the doctrine of the original sin predominated. In Peter Harrison's opinion "it is no exaggeration to say that this dogma dominated the theological agenda and became a crucial point of reference in broader social and intellectual discussions". ${ }^{10}$

The early modern preoccupation with sin meant that, in the realm of epistemology, error was often referred to or even equated with sin, and the propensity of men to perceived false claims as the true ones was attributed to Adam's Fall. Discussions of that nature explain why philosophers of the seventeenth century were so often preoccupied with error and its prevention. They commonly assumed that an error avoidance was not merely a necessary condition for knowledge; it is in fact sufficient for it. ${ }^{11}$ But if the Fall had such a destructive consequences in respect to human knowledge, the situation of mankind beforehand must have been opposite. And in fact, there was a very long tradition according to which Adam was in possession of the perfect knowledge. One of its implications was a very strong belief that human minds had originally been designed to know the truth and that was possible to reinstate, or at least to come much closer to the original state of the human mind. The way to achieve that goal was to identify and eliminate those impediments that arose as a consequence of the Fall. If it was successful, the mind would once again, of its own nature, arrive at truth or at least be better equipped to do so. Francis Bacon saw in sciences the possible way to restore, or at least

${ }^{9}$ C. Hill, "Sin and society" in: Collected Essays of Christopher Hill, University of Massachusetts Press, Amherst 1986, v. 2, p. 125.

${ }^{10} \mathrm{P}$. Harrison, The fall of man and the foundations of science, Cambridge University Press, Cambridge 2007, pp. 2-3.

${ }^{11}$ T. Lennon in his Introduction to Malebranche's Search after truth points out the sufficiency of avoidance of error as a necessary condition for knowledge. He indicates also "the noncognitive sources of error. The will has a natural and ineradicable impulse to seek certain ends that has been corrupted by Original Sin. The will's impulse has been diverted, or made capable of being diverted, from its true good into inclinations which precipitate false judgments in their favor. The passions are those inclinations that are occasioned by agitations in the state of the body and that are concerned with the good of the body" (T. Lennon, "Introduction" in: N. Malebranche, The Search after truth, tr. and ed. by T. Lennon, Cambridge University Press, Cambridge 1997, p. XII and XIV). 
repair, the losses to knowledge that had resulted from the Fall. ${ }^{12}$ His emphasis lay on cleansing the mind of those flaws introduced by the original sin. Describing his goal as 'the true end and termination of error', he suggested that this could only be accomplished if knowledge was 'discharged of that venom which the serpent infused into it'. Robert Hooke, a prominent member of the Royal Society, declared that "every man, both from a deriv'd corruption, innate and born with him, and from his breeding and converse with men, is very subject to slip into all sorts of errors... These being the dangers in the process of humane Reason, the remedies of them all can only proceed from the real, the mechanical, the experimental Philosophy"."13

Experimental philosophy was obviously not the only solution proposed to overcome the inevitable shortcomings of the fallen minds. There was a general consensus concerning the imperfections of the intellect and the need to overcome its weaknesses, but the ways of correcting these defects varied considerably. The differences stemmed primarily and intimately from varied analyses of the specific effects of the original sin. Depending on an adopted position on that matter, philosophers accorded differing priorities to the proposed sources of knowledge, be it reason and innate principles, the senses, observation, and experimentation; or divine revelation through the scriptures or personal inspiration. Similar considerations applied to the certitude that could be ascribed to various forms of knowledge. And thus, when Descartes asserted so confidently that the 'natural light' of reason could provide the basis of a complete and certain science, he must have accepted a certain premise, namely that the natural light and the divine image survived, so to speak, even in fallen human beings. This position was thoroughly unacceptable for those who believed that the Fall had erased the divine image and extinguished the natural light. According to this latter view, if knowledge were possible at all, it would be accumulated through hard work, through trials and the testing of nature, and would bring at most a modest knowledge that did not penetrate to the essences of things and was at best probable rather than certain. The experimental approach to knowledge was an instance of such a position that was modest and skeptical to some extent. ${ }^{14}$

\footnotetext{
12 "For man by the fall fell at the same time from his state of innocency and from his dominion over creation. Both of these losses however can even in this life be in some part repaired; the former by religion and faith, the latter by arts and sciences" (F. Bacon, Novum Organum II, LII, ed. I. H. Anellis, 2008, p. 101).

${ }^{13}$ R. Hooke, Micrographia, London 1665, Preface, p. II.

${ }^{14}$ P. Harrison, The fall of man and the foundations of science, pp. 6-7.
} 
At the bottom of all these considerations lay an issue of enormous importance, namely, whether Adam's knowledge was a supernatural gift, and whether the Fall consisted only in a loss of supernatural gifts. One should not underestimate the significance of this recondite theological issue for seventeenth-century philosophical discussions since the answers to these questions bore far-reaching consequences. If Adam's abilities, on the one hand, had resulted from a supernatural gift, the prospects for recovery of that knowledge by natural means in the present life would be limited. If, on the other hand, Adam's knowledge was either innate, being an intrinsic part of human mind, or acquired through experience based on some 'natural' human cognitive powers, his losses could be understood in terms of a disordering of his natural faculties. Lack of reliable knowledge and all the difficulties with acquiring it would thus be the result of the corruption of human nature rather than the withdrawal of any supernatural abilities. In this latter case, the chances of regaining knowledge by natural means were somewhat better, for it would not be unreasonable to seek better identifiable natural flaws in the functioning of body and mind. ${ }^{15}$

Although there was no unanimity on the nature and consequences of the Fall during this period, there was general agreement that questions relating to human nature and knowledge could not be addressed adequately without a consideration of the original sin. Varying estimates of the severity of the Fall gave rise to different assessments of human capacities and strategies for knowledge acquisition.

The above mentioned theological disputes of the seventeenth-century England created a certain intellectual frame of reference of particular importance. And in that very context we may put now the discussion between R. Boyle and H. More. What must be emphasized, More and Boyle have taken opposite stands on the nature and certitude of human knowledge. It is related to their positions about capacities of human cognitive powers, affected or not by Adam's Fall. And so, the Cambridge Platonists generally estimated the competence of reason very high. ${ }^{16}$ Benjamin Whichcote opposed, in his view, the exaggerated pessimism of the Puritan party and insisted that the human mind bore within it a number of 'truths of first inscription' which could not be erased. These universal principles, manifested primarily as intuitions of

${ }^{15}$ Ibid., p. 158.

${ }^{16}$ S. Hutton, “The Cambridge Platonists" in: S. Nadler (ed.), A Companion to Early Modern Philosophy, Blackwell, Oxford 2002, pp. 308-19; P. Harrison, 'Religion' and the Religions in the English Enlightenment, Cambridge University Press, Cambridge 1990, pp. 28-60. 
basic moral truths, represented 'the light of God's creation', and were 'immutable and indispensable. ${ }^{17}$ Henry More defended the position that to deny the efficacy of fallen reason completely was to destroy human nature itself: "To take away Reason therefore, under what Fanatick pretense soever, is to disrobe the Priest and despoil him of his Breast-plate, ... For take away Reason, and all Religions are alike true, as the Light being removed, all things are of one colour". ${ }^{18}$ It is also significant that the Cambridge Platonists understood the Fall in terms of embodiment and attachment to material things, and that is why they granted primary place to reason rather than the senses in the acquirement of knowledge. John Smith thus recommended that reason " $r e$ tract and withdraw it self from all Bodily operation whensoever it will nakedly discern truth". ${ }^{19}$ Small wonder that the Platonists were so strongly drawn, initially at least, to the Cartesian account of knowledge.

The position of Robert Boyle was more complicated. He does admit the Fall, yet he was reluctant to attribute all the limitations of human knowledge to Adam's sin. It is significant, for example, that he was cautious about endorsing the tradition that accorded encyclopaedic knowledge to Adam. "If Adam were now alive, and should survey that great variety of man's productions, he would admire to see what a new world, as it were, or set of things has been added to the primitive creatures by the industry of his posterity". ${ }^{20}$ All the knowledge about the created world, including what Adam had known in Paradise, was in his view necessarily limited by finitude. Only with the resurrection will we be able to come into possession of true science. For Boyle, then, the root cause of the defects of human knowledge seemed not to be the sinful and corrupted condition of humanity but rather an original set of deficiencies placed on the mind and body that were present even in their first creation. He was to speak of "a necessary Imperfection of Humane Nature, that whilst we remain in this mortal condition, the Soul being confin'd to the dark prison of the Body, is capable . . but of a dim knowledge". ${ }^{21}$ For this

${ }^{17}$ B. Whichcote, The Works of the Learned Benjamin Whichcote, D. D., 4 vols., Aberdeen, 1751, vol. 3, p. $20 \mathrm{ff} ., 31$.

${ }^{18}$ H. More, A Collection of Several Philosophical Writings, Preface, p. VI.

${ }^{19}$ J. Smith, Select Discourses, London 1660, p. 80.

${ }^{20}$ R. Boyle, Usefulness of Natural Experimental Philosophy, Oxford 1663, p. 20. http://quod.lib. umich.edu/e/eebo/A29031.0001.001/1:5?rgn=div1;view=fulltext (access 14.07.2017).

${ }^{21}$ R. Boyle, The Excellency of Theology compar'd with Natural Philosophy, London 1674, p. 154. http://quod.lib.umich.edu/e/eebo/A28966.0001.001/1:7.2? rgn=div2;view=fulltext (access 14.07.2017). 
reason, our knowledge does not extend to the essences of things, nor even to every object, but only to those "as God thought fit to allow our minds in their present (and perchance lapsed) condition".22 Boyle had no serious doubts about the Fall; he was rather uncertain of how it affected our capacity for knowledge. It seems he regarded the Fall as evidence of our tendency to make mistakes in the process of attaining knowledge rather than as the ultimate cause of them. And these limitations were necessary because they followed from the kind of creatures we are - souls imprisoned in bodies. Our modest position as creatures in the scale of being points out certain limits within our capacity for knowledge, particularly when we compare ourselves to omniscient God. All of this means that we must entertain only modest expectations of the reach of natural philosophy. Thus, Boyle frequently stresses the fact that there is no 'clearness and certainty' in physics. The experimental approach is justified primarily by appeals to the weakness of our sensory and cognitive capacities. "For many seventeenth-century English thinkers these weaknesses were understood as consequences of the Fall. And so the methodological strictures of particular programmes of natural philosophy - experimental method being perhaps the best example - were understood as applying necessary external constraints to fallen minds which, left to their own devices, would simply fail to accumulate any useful knowledge of the natural world". ${ }^{23}$

If we accept the importance of the above mentioned theological issues in the XVII ${ }^{\text {th }}$ century philosophy we must look at the More-Boyle's discussion from a different perspective. A proper understanding of this dispute reveals much not only about the nuances of the seventeenth-century matter theory or the dawn of experimental approach in sciences, but also the relevance of some fine distinctions to wider, theological in this case, issues in the intellectual history of the seventeenth-century England.

As John Henry pointed out, the question about the certitude of human knowledge in More's and Boyle's philosophies must be thus referred to another one, namely that of the nature of God's omnipotence. ${ }^{24}$ In the seventeenth century England, there were two competing theories regarding that

\footnotetext{
${ }^{22}$ R. Boyle, Things above reason, London 1681, p. 85. http://quod.lib.umich.edu/e/eebo/ A28958.0001.001? view=toc (access 17.07.2017).

${ }^{23}$ P. Harrison, The fall of man and the foundations of science, p. 220.

${ }^{24} \mathrm{~J}$. Henry, Henry More versus Robert Boyle: the spirit of nature and the nature of providence in: Henry More (1614-1687).Tercentenary studies, ed. by S. Hutton, Kluwer Academic Publishers, Dordrecht 1990, pp. 55-76.
} 
problem - so called intellectualist and voluntarist theologies. And, as we can easily guess, More and Boyle took different positions in this respect.

Providential theology was known under various terms, intellectualism, necessitarianism, theological optimism, or simply rationalism. What this means is that the dominant attribute of God is intellect or reason, and that God's intellectual powers, existing yet before the Creation, have been a necessary source of certain essential characteristics inherent in the very nature of things. These essentials included moral concepts such as good and evil, justice and injustice, as well as natural concepts such as the distinction between body and soul. H. More was a vigorous proponent of such a theological position. And so, More consequently maintained that, having recognised such essential principles, God, because of His supreme goodness, had to create the world in accordance with the moral demands placed upon Him by His own goodness and in accordance with the essential relationships inherent in the nature of things. So, in a sense, by His absolutely good and omniscient nature God was forced to create the world in the very way it has been created. Because of His own nature, God could not even choose not to create the World, and the World that He had to create was the only one possible, namely, of course, the best of all possible worlds.

One of the important features of the intellectualist theology is the underlying assumption that there is nothing arbitrary in the system of the world. The eternal and immutable set of 'mutual respects and relations' between things is inherent in the very nature of things themselves. Accordingly, the system of the World can be arrived at by purely rationalist means.

Boyle, on the other hand, was a proponent of the voluntarist theology that stressed God's prevailing attribute, the will. According to this perspective, the world was created by the power of God's arbitrary will that was utterly impenetrable to human minds. The world was a set of contingencies dependent only on God's thoroughly free decisions. What order exists in the world is not due to any limitations upon God's creative freedom by immutable essences inherent in things themselves (being put there by the divine mind), but is simply due to God's arbitrary decision to make it so. And if the nature of the world system is arbitrary and contingent the pure reasoning in its attempt to discover that system must be quite futile. In moral philosophy, this meant that More's 'eternal and immutable' principles were replaced by the notion that things are good and just, because 
God wills them so to be. While, in natural philosophy, as it is well-known, voluntarism underwrote empiricism..$^{25}$

There were obviously certain consequences of taking these positions with respect to More and Boyle's views on natural philosophy. In the course of discussion with Boyle, More insisted that the existence of the Spirit of Nature is not only sufficiently argued but also that its existence and activity in the natural world is simply undeniable, and that position was intimately connected with another one, viz. that the whole matter is utterly dead and inert. The existence of the Spirit on Nature was to be one of the 'eternal and immutable' truths which even God cannot change. The rationally established dichotomy between spirit and matter was intended to extend the realm of those logical 'contradictions' that were beyond God's powers to accomplish. In the same way, God's omnipotence did not enable him to square the circle, so God could not endow matter with the inherent principles of activity. To speak of this, according to More, would be a contradiction in terms. From More's point of view, the theory of strict dichotomy between matter and spirit had to be apodictic and undeniable as it was an essential part of his wider philosophical and religious intentions. The theory was a stepping stone for his proof of immaterial substance, and that, in turn, made it possible to go on to prove the existence of God and the immortality of the soul. Secondly, if the distinction between the two substances, material and immaterial, could be demonstrated as both logical and natural, such conclusion would provide clear confirmation of More's brand of rational, providential theology in which even the Creator had to follow eternal and immutable laws. For him, the Spirit of Nature had to be a necessary factor of the world. To give way on the existence of the Spirit of Nature was to give way on the concepts of eternal and immutable justice and goodness, and this, in turn, as More strongly believed, was to lay "the Foundations of Rantism, Debauchery and all Dissoluteness of Life" 26 because it was only God's awareness of More's notion of justice which could guarantee that the true believer would be rewarded while the wicked would be punished, "if the measure of his [God's] Providence be his mere Power, Will or Sovereignty no man living can tell what to expect in the conclusion. All true Believers may be turned into Hell, and the

\footnotetext{
${ }^{25}$ J. Henry, Henry More versus Robert Boyle, p. 65.

${ }^{26} \mathrm{H}$. More, Two choice and useful treatises, London 1682, p. 181.

http://quod.lib.umich.edu/cgi/t/text/text-idx?c=eebo;idno=A70182.0001.001 (access 21.07.2017).
} 
wicked onely and the Blasphemer ascend into the Regions of Blis. For what can give any stop to this but God's Justice, which is a branch or mode of his Goodness?".27

Boyle's response, on the other hand, can be seen as just one manifestation of his consistent scepticism and anti-dogmatism. In his Considerations about the Reconcileableness of Reason and Religion of 1675, Boyle made it very clear that he believed no rationalist system of philosophy or theology could be trusted to generate new knowledge: "there are very few conclusions that we make, or opinions, that we espouse, that are so much the results of our reason, that no personal disability, prejudice, or fault, has any interest in them ... the very body of mankind may be imbued with prejudices, and errors, that from their childhood, and some also even from their birth, by which means they continue undiscerned, and consequently unreformed".28

But More's dogmatic rationalism was only a part of the problem. Boyle was also aware that More's dogmatism was intrinsically connected with his views on God and the nature of Providence, and that these views were totally unacceptable to Boyle himself. Boyle believed that the usefulness of his natural philosophy lay in its ability to demonstrate the existence and omnipotence of God. Contrary to popular misconceptions about the mechanical philosophy, Boyle wished to argue that the fact that the world can be explained in mechanical terms points inevitably to the existence of omnipotent God. And what is more, it is only our belief in omnipotent Creator that enables us to see the world as a mechanical system. Even Greek Philosophers were convinced of the existence of God but this did not lead them to suppose or accept the existence of a separate Spirit of Nature. On the contrary, "yet taking no notice of an immaterial principium hylarchicum, they believed things to be managed in a meer physical way according to the General Laws, settled among things Corporeal, acting upon one another". 29

${ }^{27}$ H. More, Divine dialogues, London 1668, pp. 177-178.

http://quod.lib.umich.edu/cgi/t/text/text-idx?c=eebo;idno=A51294.0001.001 (access 20.07.2017).

${ }^{28}$ R. Boyle, "Some Considerations about the Reconcileableness of Reason and Religion", in: The Works Of The Honourable Robert Boyle, vol. 4, p. 164.

https://books.google.pl/books?id=aUxTAAAAcAAJ\&printsec=frontcover\&hl=pl\#v=onepage \&q\&f=false (acces 21.07.2017).

${ }^{29}$ R. Boyle, "Hydrostatical discourse", in: The Works Of The Honourable Robert Boyle. In Six Volumes, vol. 3, p. 628.

https://books.google.pl/books?id=O0xTAAAAcAAJ\&printsec=frontcover\&hl=pl\#v=onepage \&q\&f=false (access 21.07.2017). 
Boyle declared that his own attempts to account for physical phenomena in terms of "the motion, bigness, gravity, shape and other mechanical affections of the small parts of liquors" were intended to prove that the world was "at first made [and] continually preserved by God's divine power and wisdom". ${ }^{30}$ While he dismisses the Spirit of Nature as "a meer Hypothesis", the gravitation of water, occult though it may be, is "directly proved by particular Experiments". He admitted that he did not know what "the cause of gravity" is; nevertheless, he was convinced that his experiments make it manifest that "there is such a quality" in bodies. The clear implication of this, as far as Boyle was concerned, is that God has the power to endow matter with active principles such as gravity or simply motion. ${ }^{31}$

Now we can understand much better why the strict dualism of Henry More, in which matter was necessarily inert and the whole activity had to be attributed to a spiritual or immaterial operator, was not accepted by Robert Boyle. Conversely, Boyle's belief that God could endow matter with 'essential modifications' which included motion and 'seminal rudiments or principles' was unacceptable to Henry More. More's insistence that all the activities of a body, even falling down when it is released from a height, must be attributable to an immaterial principle, the Spirit of Nature, was intimately bound up with a number of theological notions to which Boyle could not or would not subscribe.

The endeavour to better understand the modern philosophy, its roots and consequences, has already got its own history. 30 years after publishing Leviathan and the air-pump, giving answers 'historical in character' seems to become a commonplace now. The history of philosophical thought must be put in the context of contemporary culture: otherwise, what we 'discover' might be some kind of caricature formed primarily by our modern understanding of what is essential for acquiring 'genuine' knowledge. In the case of the seventeenth century culture, we must not overlook the fact that it was driven primarily by religious issues which cannot be ignored if we would like to understand the actual thought of that time. As R. Popkin puts it: "If the religious context is as rich as I suggest - richer than the scientific one, at least for the seventeenth century - perhaps we can find out much more about our own intellectual heritage, and hopefully, much more scholarly work ...,

\footnotetext{
${ }^{30}$ Ibid., p. 608.

${ }^{31}$ J. Henry, Henry More versus Robert Boyle, p. 61, quotations R. Boyle, Hydrostatical discourse, ibid., pp. 601, 624 .
} 
in term of interpreting the religious contexts. When this is done we may be in a much better position to understand how we actually got from the past to the present. And we may be in a much better position to evaluate the equivalent or analogous situations in which present day thought is enmeshed - our religious and ideological contexts - and how much they shape our concerns, our theories, [and] our visions". ${ }^{32}$

\section{Bibliography}

\section{Primary sources:}

Bacon, Francis. Novum Organum, ed. I. H. Anellis, 2008.

Boyle, Robert. "New experiments about differing pressure". In: The Works of the Honourable Robert Boyle. London 1772, v. 3.

Boyle, Robert. Usefulness of Natural Experimental Philosophy. Oxford $1663 \mathrm{http} / /$ quod.lib.umich.edu/e/eebo/A29031.0001.001/1:5?rgn=div1;view=fulltext (access 14.07.2017).

Boyle, Robert. The Excellency of Theology compar'd with Natural Philosophy. London 1674 http://quod.lib.umich.edu/e/eebo/A28966.0001.001/1:7.2?rgn=div2;vie$\mathrm{w}=$ fulltext (access 14.07.2017).

Boyle, Robert. Things above reason. London $1681 \mathrm{http}: / /$ quod.lib.umich.edu/e/eebo/ A28958.0001.001?view=toc (access 17.07.2017).

Boyle, Robert. "Some Considerations about the Reconcileableness of Reason and Religion". London 1675. In: The Works Of The Honourable Robert Boyle. London 1772 , v. 4.

Boyle, Robert. "Hydrostatical discourse". In: The Works Of The Honourable Robert Boyle. London 1772, v. 3.

Hooke, Robert. Micrographia. London 1665.

More, Henry. "An Antidote against atheism". In: A Collection of Several Philosophical Writings. London 1662.

More, Henry. Remarks on two late ingenious discourses. London 1676.

http://quod.lib.umich.edu/e/eebo/A51313.0001.001/1:7.17?rgn=div2;view=fulltext (access 19.07.2017).

More, Henry. "Preface". In: A Collection of Several Philosophical Writings. London 1662.

More, Henry. Two choice and useful treatises. London 1682.

${ }^{32}$ R. Popkin, The Third Force in Seventeenth-Century Thought, Brill, Leiden 1992, p. 284. 
http://quod.lib.umich.edu/cgi/t/text/text-idx?c=eebo;idno=A70182.0001.001 (access 21.07.2017).

More, Henry. Divine dialogues. London 1668.

http://quod.lib.umich.edu/cgi/t/text/text-idx?c=eebo;idno=A51294.0001.001 (access 20.07.2017).

Patrick, Simon. A brief account of the new sect of latitude-men. Together with some reflections upon the new philosophy. London 1662.

https://babel.hathitrust.org/cgi/pt?id=uc1.32106009838514;view=1up;seq=9 (access 14.07.2017).

Smith, John. Select Discourses. London 1660.

Whichcote, Benjamin. The Works of the Learned Benjamin Whichcote, D. D., 4 vols., Aberdeen, 1751.

\section{Secondary sources:}

Harrison, Peter. The fall of man and the foundations of science. Cambridge: Cambridge University Press, 2007.

Harrison, Peter. 'Religion' and the Religions in the English Enlightenment. Cambridge: Cambridge University Press, 1990.

Henry, John. "Henry More versus Robert Boyle: the spirit of nature and the nature of providence". In: Henry More (1614-1687). Tercentenary studies. Edited by S. Hutton. Dordrecht: Kluwer Academic Publishers, 1990.

Hutton, Sarah. "The Cambridge Platonists". In: A Companion to Early Modern Philosophy. Edited by S. Nadler. Oxford: Blackwell, 2002.

Hill, Christopher. "Sin and society". In: Collected Essays of Christopher Hill, vol. 2. Amherst: University of Massachusetts Press, 1986.

Lennon, Thomas. "Introduction". In: N. Malebranche. The Search after truth. Translated and edited by T. Lennon. Cambridge: Cambridge University Press, 1997.

Noble, David. The religion of technology. The divinity of man and the spirit of invention. New York: A.A. Knopf, 1998.

Popkin, Richard. The Third Force in Seventeenth-Century Thought. Leiden: Brill, 1992.

Reid, Jasper. The Metaphysics of Henry More. Dordrecht - Heidelberg - New York London: Springer, 2012.

Shapin, Stephen, Schaffer, Simon. Leviathan and the air-pump. Hobbes, Boyle, and the experimental life. Princeton and Guildford: Princeton University Press, 1985.

The millenarian turn: millenarian contexts of science, politics, and everyday angloamerican life in the seventeenth and eighteenth centuries, ed. J. E. Force and R. H. Popkin, Dordrecht: Springer Science-Business Media, 2001. 


\section{Summary}

The second half of the seventeenth century witnessed in England some fundamental differences of opinion over the nature and sources of knowledge. Historians of philosophy interpret discussions ensuing from that differences stressing importance of the whole intellectual picture of that period and pointing out to some particular reasons that were to drive philosophers in taking their epistemological and metaphysical stances. The present paper is an attempt to stress the importance of religious context in evolving of philosophical thought of that period. In the case of dispute between R. Boyle and H. More about the status and possible usage of knowledge gained through the experimental method, the starting point of controversy is the differing views on some theological issues. The issue of God's omnipotence, which Boyle interpreted in the framework of voluntarist, and More of intellectualist theology, proved to be one of the most important of them. Consequently, Boyle believed that human knowledge may be only probabilistic, and the results of experiments cannot be used to formulate theses that would be absolute in character. More, in turn, maintained that human knowledge can be a reflection of God's absolute knowledge, and the results of experiments can be used to justify metaphysical theses, above all of the existence of God.

Keywords: Experiment, God, voluntarism, intellectualism, natural philosophy, absolute knowledge, probable knowledge 